\section{Livet med Tourette og tvang}

Sandstrak P.

Mr Tourette og jeg

427 s, ill. Oslo: Cappelen Damm, 2009.

Pris NOK 349

ISBN 978-82-02-29079-5

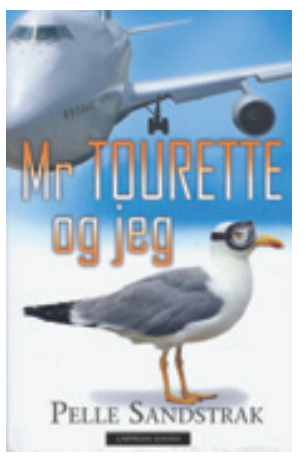

Boken handler om forfatterens liv med Tourettes syndrom. Pelle Sandstrak ble født i Namdalen i 1960-årene. Han var aktiv som gutt, ivrig ishockeyspiller og ville bli hvalfanger eller sportskommentator. Men i tiårsalderen begynte tics og tvangstanker å prege livet hans. Det var særlig tvangen som fikk store konsekvenser. Han greide ikke å lære matematikk fordi han måtte unngå bokstavene $\mathrm{x}, \mathrm{y} \mathrm{og} \mathrm{z}$ som betyr blod, smitte og død. Han måtte utføre ritualer foran porten hjemme for å unngå katastrofer.

Ungdomsårene ble preget av impulsiv atferd, lyder og tidkrevende ritualer. Pelle var populær hos jentene og god i sport, og med god støtte i foreldrene greide han seg noenlunde. Men han ble stadig mer fortvilt over alt det rare han tenkte og gjorde og skammet seg over seg selv. Han ble en mester i å spille skuespill for å kamuflere ticsene og ritualene, så atferden hans skulle virke mindre merkelig.

Familien søkte hjelp overalt og var i kontakt med både psykiatere, psykologer og alternative behandlere. Men ingen stilte riktig diagnose. Sandstrak flyttet etter hvert til Oslo og livnærte seg av strøjobber. Tvangstanker og ritualer tok mer og mer av hverdagen og truet også den fysiske helsen alvorlig. Sykdommen styrte nå livet nesten fullstendig. Først i en alder av 25 år, og ved en tilfeldighet, kom han i kontakt med svenske psykiatere og psykologer som stilte riktig diagnose og tilbød god behandling. Da begynte en lang og tøff kamp for å bli bedre og få et godt liv.

Sandstrak ønsker å formidle hva som kan ligge bak spesiell atferd, og gjør det på en levende, nyansert og humoristisk måte. Han er ikke bitter over alle årene uten diagnose og behandling. Han ser fordeler med å ha Tourettes syndrom og synes ikke man skal bli for normal. Språket er medrivende, med snert og mange innfall, og det er mange pussige og morsomme betraktninger. Slik blir denne dramatiske livshistorien, som også handler om angst og smerte, både gripende og underholdende. Skulle jeg innvende noe, måtte det være at boken er i lengste laget. Forfatteren bruker mye plass på å beskrive alle de plagsomme episodene som ung voksen. Her kunne det med fordel vært strammet inn en del. Jeg ville ellers gjerne lest litt mer om selve behandlingsprosessen, som bare er beskrevet i noen få korte kapitler på slutten.

For alle fagpersoner som møter barn, ungdom og voksne med tics og tvangstilstander er dette særlig relevant. Men alt fagpersonell innen psykisk helse kan ha nytte av denne boken, som nok også har interesse for en større leserkrets.

\section{Torunn Stene Nøvik}

Barne- og ungdomspsykiatrisk avdeling Sykehuset Buskerud

\section{Lite nytt \\ om brukererfaringer, læring og mestring}

Heggdal K.

\section{Kroppskunnskaping}

Pasienten som ekspert i helsefremmende

prosesser. 350 s, ill. Oslo: Gyldendal

Akademisk, 2008. Pris NOK 449

ISBN 978-82-05-33172-3

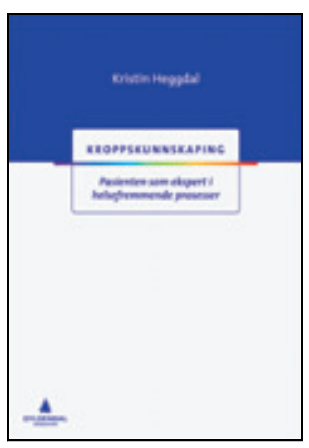

Forfatteren er forsker med tilknytning til Diakonhjemmets sykehus og ansatt som førsteamanuensis ved Diakonhjemmets høgskole. Hun har arbeidet i 15 år med forskning om Kroppskunnskaping og har en dokvitenskap om dette temaet. torgrad i sykepleie-

Boken er inndelt i ni kapitler. I de to første presenteres Kroppskunnskaping som «en grunnleggende prosess for utvikling av personlig kunnskap om egen kropp, mestring, helse og velvære. Kroppskunnskaping er en naturlig helsefremmende prosess når mennesker rammes av langvarig sykdom, skade og funksjonssvikt». Forfatteren angir at pasientens kunnskap om seg selv utvikles når personen erfarer sykdommen over tid og deltar i ulike nivåer av dialog, slik som a) å lytte til og reflektere over kroppens tegn og symptomer, b) å lese og lytte til informasjon om helse og c) å samtale med helsepersonell og nære andre. Slik blir ulik type erfaringer og kunnskap integrert i en personlig kunnskapsbase, og personens tidligere erfaringer med en frisk kropp blir erstattet av nye erfaringer når man har fått en sykdom. Kroppskunnskapingsprosessen beskrives i kapittel 3 i regnbuemodellen: Fiolett fase preges av uvisshet og flukt fra den syke kroppen, blå fase av tap av livsutfoldelse, grønn fase av kroppslig læring og styrket håp, og rød fase preges av integrert kroppskunnskap med nye muligheter for livsutfoldelse og helse. Kroppskunnskapen som erverves handler om å lytte til kroppens signaler, lære seg hva man tåler og sette de nødvendige grensene, for eksempel for aktivitet eller hva man bør spise.

I kapittel 4-8 forsøker forfatteren å knytte an til en rekke teorier og begreper, for eksempel kroppsfenomenologi, kunnskapsteori, salutogenese, rekonvalesens og kroppens sosiale kontekst, men uten at sammenhengen mellom disse og Kroppskunnskaping blir tydelig. I siste kapittel beskrives Kroppskunnskaping i praksis, der utdrag av seks samtaler mellom forfatteren og en pasient gjengis. Samtalene forløper slik man kan forvente mellom en pasient og en helsearbeider.

Forfatteren formidler engasjement for pasienter med langvarige sykdomsplager og et ønske om å bistå. Hovedbudskapet er at helsepersonell må lytte til pasientenes fortelling om sine opplevelser og erfaringer, og at både brukerkunnskap og fagkunnskap er nødvendig for at hjelperen skal kunne bistå mennesker med langvarige sykdommer. Kroppskunnskaping angis som en ny metode som trengs i helsevesenet for å oppnå dette. Etter denne leserens mening bringer verken modellen eller den kliniske metoden noe nytt. Fremstillingen er svært ordrik og preget av gjentakelser, og det er vanskelig å finne en rød tråd i teksten. Mange har skrevet bedre om brukerperspektiv og brukermedvirkning og om lærings- og mestringstilnærming innen helsefagene de senere årene.

Som målgruppe angis ulike grupper 
helse- og sosialpersonell, både studenter og klinikere. Imidlertid er Kroppskunnskaping et registrert og beskyttet varemerke, og det er knyttet vilkår til bruk av konseptet i praksis (www.kunnskaping.no).

Sissel Steihaug

Avdeling for helsetjenesteforskning SINTEF

Oslo

\section{Ikke bare jeg?}

Eggen I.

\section{Bare jeg..}

En dissosiativ identitetsforstyrrelse. $355 \mathrm{~s}$ Stavanger: Hertervig forlag, 2008. NOK 149 ISBN 978-82-8216-025-4

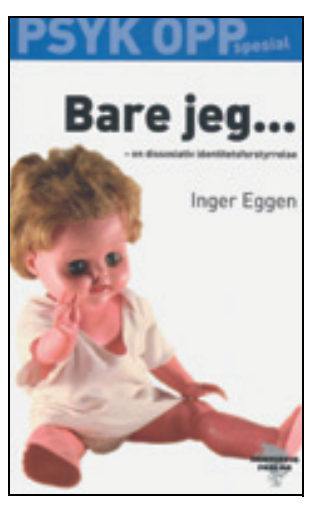

Inger Eggen gir oss en sterk, ærlig og gripende beretning om en oppvekst og en personlighetsutvikling med en selvopptatt mor, en hatefull bror og - verst av alt - en alkoholisert og overgripende far. Bare jeg... er utgitt i serien til stiftelsen Psykiatrisk Opplysning og er således ment å bidra til mer åpenhet omkring psykiske lidelser, og ikke minst å gi alvorlige tilstander, i dette tilfellet en dissosiativ identitetsforstyrrelse, et ansikt. Det gjør Eggen til gagns og på en så overbevisende måte at man som leser sitter igjen med inntrykk av at det i tillegg til det dissosiative også foreligger en multippel personlighetsforstyrrelse. For det er et omfattende personlighetsgalleri som vi blir kjent med og som befolker hennes hage, utgjør forskjellige deler av henne og tar styringen over hennes atferd i ulike situasjoner.

At forfatteren har hatt behov for å «skrive seg igjennom» sin lidelse, er fullt forståelig, og hun nærmest tømmer ut sitt sjeleliv i usensurert form fra side til side. I det ligger noe av vanskeligheten $i$ å gi en anmeldelse en balansert og «rettferdig» form. Som leser kan man få følelsen av aldri å bli ferdig, mye av det samme gjentar seg - med de indre dialogene i en kaotisk form, som naturlig nok avspeiler hennes følelses- og tankeliv, men som kan virke noe utmattende på undertegnede.

Når det er sagt, skal Eggen ha ros for å ha gitt sitt bidrag til avsløringen av det besteborgerlige fasadespill som omgir for mange familier i vårt samfunn og som i all sin tilsynelatende vellykkethet produserer en slik tragedie for et barn.

Budskapet er derfor rettet til allmennheten - uansett profesjon. Det er verdifullt og bevisstgjørende og fortjener oppmerksomhet, men formen kan gjøre at noen faller av lasset underveis. Holder man imidlertid ut til slutt, făr man belønning gjennom det glimtet av håp som forfatteren ser og vil dele med oss i de siste setningene: «... med hjelp til å forstå min indre verden for å akseptere skadene som ble påført meg som barn, kan jeg en gang oppnå å dirigere personene i hagen min. Det er mulig at vi kan spille sammen og lytte til hverandre. Det kan bli kvinnen med navnet Inger. En gang. Det er visst mulig å erkjenne at livet ble slik det ble, finne nye toner og ny musikk som kan gi mening og glede. For meg. For Inger. Kanskje.»

Med dette håp for øye og i takknemlighet til sine terapeuter, uttrykt i forordet, kan Eggen makte å fri seg fra dissosiasjonen og ta herredømme over de multiple personlighetene som har befolket hennes hage - for dermed endelig å kunne spille på lag med seg selv.

\section{Tore Gude}

Modum Bad

Vikersund

\section{Likeverdig samarbeid i psykiatrien}

Storm M.

Brukermedvirkning i psykisk helsearbeid

156 s, tab, ill. Oslo: Gyldendal Akademisk, 2009. Pris NOK 235

ISBN 978-82-05-39166-6

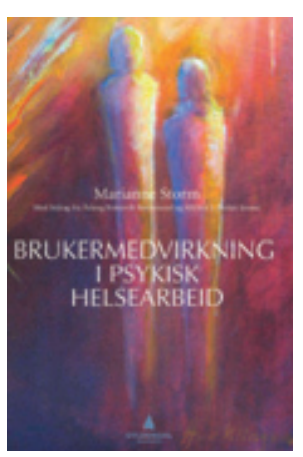

Hensikten med boken er å gi konkrete innspill til arbeidet med brukermedvirkning i et samarbeid mellom pasienter, deres pårørende, brukerrepresentanter og helsepersonell innen psykisk helsevern. Forfatteren er sykepleier med grunnfag og mellomfag i psykologi og hovedfag i helsefag. Boken har bidrag fra Åslaug Botnevik Rennesund, som har mastergrad i psykologi, og Målfrid J. Frahm Jensen som er hjelpepleier, lyriker og skribent.

De nye helselovene bereder grunnen for en ny måte å samarbeide på, der pasientene ikke lenger er passive mottakere av ekspertenes anbefalinger og råd, men der det stilles sterkere krav til den informasjon som skal gis av helsepersonell og ikke minst den innflytelse pasientene skal ha på sin egen behandling. I psykiatrien kan dette være spesielt vanskelig, men her balanseres det fornuftig i boken, der det understrekes at tilnærmingen må være fleksibel og tilpasses pasientens tilstand til enhver tid. Siktemålet er å ansvarliggjøre pasienten og sette verdiene autonomi og selvstendighet i fokus. Pårørende har også en viktig rolle, og det gis anbefalinger for hvordan de best kan tas med $i$ arbeidet rundt pasienten og samtidig bli ivaretatt med sine individuelle behov.

I boken gjennomgås et konkret og praktisk opplegg av ti måneders varighet, med utgangspunkt i hovedforfatterens og de øvrige bidragsyternes erfaringer fra avdelinger i Stavanger og Ryfylke distriktspsykiatriske senter. Det beskrives en innledende kartleggingsfase med etablering av styringsgruppe, dialogkonferanse (seminar), personalmøter med bruk av ekstern fasilitator (et bedre ord enn veileder i denne sammenhengen), arbeid i temagrupper, undervisningsopplegg med faglig påfyll (kunnskapsforum), og det gis en del tips om hvilke fremgangsmåter som kan være nyttige når grupper går i stå og ikke kommer videre. Til sist gis det innspill som kan være hensiktsmessige for å kartlegge om opplegget har gitt noen effekt, og som kan være utgangspunkt for videre oppfølging.

De konkrete beskrivelsene er nyttige, men boken skjemmes av for mange gjentakelser og selvfølgeligheter. Slik sett hadde et mer kortfattet hefte vært mer anvendelig i praksis. Likevel kan den trygt anbefales for de miljøer som ønsker en ledesnor for sitt arbeid på dette viktige feltet.

\section{Stein Opjordsmoen}

Avdeling for forskning og undervisning

Oslo universitetssykehus, Ullevål

\section{Godt om inneklima}

\section{Aas K.}

\section{Godt inneklima}

Håndboken for hjemmet. 302 s, ill. Oslo:

Cappelen Damm, 2009. Pris NOK 299

ISBN 978-82-02-29065-8

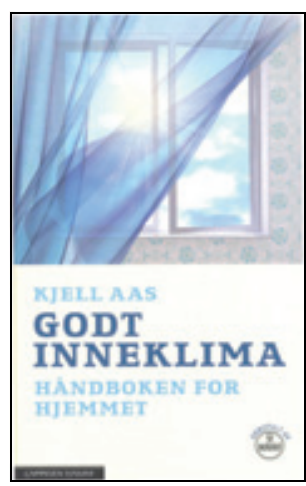

De senere årene har det vært stadig økende oppmerksomhet på inneklima. Økt kunnskap har gjort det viktig å erkjenne at inneklima er viktig for både helse og trivsel. Det er imidlertid mange aktører på banen, og for folk flest kan det være forvirrende å finne ut av hvor man skal hente nyttig informasjon.

Kjell Aas er en kjent og dyktig fagperson innenfor det norske inneklimafeltet. Her har 